\title{
OUR CASE-LAW OF CONTRACT: OFFER AND ACCEPTANCE, II.*
}

\author{
By K. N. LLEWELLYN†
}

THE PRIOR installment moved upon the premise that case-law doctrine in Contract is built around the facts of adjudication, and is likely both to reflect life-conditions and to stay moderately close to them. When in doubt whether a given body of Contract doctrine is case-law doctrine, one very hopeful approach is to examine the fact-conditions to which

*The prior articles in this series may be found in (1938) 47 YALE L. J. 1243; (1938) 48 Yare L. J. 1.

$\doteqdot$ Betts Professor of Jurisprudence, Columbia Law School.

Acknowledgments: During the interminable rewritings of this paper tov many yersons to mention in detail sacrificed time to help it into understandability. I must, however, thank L. L. Fuller particularly for his careful and helpful suggestions on the substance of a "final" draft which proved not final; also incorporated are various suggestions from William Dennis, Henry Harfield, Goble, Havighurst, Kennedy, Soia Mentschiliff, Patterson, Sharp, Warren Silver-and, as always, Emma Corstvet.

The relation of the paper to Ashley's Formation of Contrat Inter Alsentes, SEuecrod Readivgs on the Law of Contracts (1931) 281, is obvious. And Handler tells me that the analysis of Offer and Acceptance worked out on the cases and taught by Oliphant some fifteen years ago coincides in all major points with that here presented. It is probably as a consequence of this that Oliphant challenged the over-broad current statement of the "principle" that in a bilateral "both must be bound or neither is bound." IIufualify of Obligation in Bilateral Contracts at Laz' II, in Selecten Resnucs (1931) 387. For observation of the Offer and Acceptance cases forces to the conclusion that that "principle", which is a correction and limitation of an older supposed principle that "in a contract both must be bound or neither is bound," is itself still in need of further correction and limitation. I do not think Oliphant's paper wholly fair in all its implieations because the mutuality of obligation rule has a vast range of real applicability; but it is thuruughly suund in denying any conclusiveness to reasoning from mutuality, as a case-law renuirement, in any close case. See case-discussion in the next installment.

But my own essential indebtedness is to Corbin, as anyone can see on rereading his Offer and Acceptance, and Some of the Resulting Legal Relations, SEuEcted Reionos (1931) 170, (1917) 26 YaLE L. J. 169.

Authorities: Discussion of the state of the case-law must be left over, save for one matter crucial to the argument here, until the next installment. I regret this. But when familiar cases, which themselves are seen as soon as mentioned, in terms of the familiar concepts, are discussed at the same time with those familiar concepts, it becomes practically impossible for even a sympathetic reader to see that I am not writing about the formstion of "unilaterals" and "bilaterals" as familiarly defined.

Corrigendum: In part I, at 22, text and note 47 require clarification. What I wanted to say is that even three-quarters of a century after Adams : Lindsill we were, and still are, finding details still unsettled; and that the nineteenth century German thinking and decisions so carefully and skilfully canvassed by Nussbaum reached, in the Civil Code not a conclusion, but a "solution" whose detailed implications will be giving their troubles to the post-Code cases. The type of convergence to be expected despite different baselines is found, e.g., when silence can operate to obligate an offeree, in either system. 
that doctrine purports to apply. If it fits those conditions, it is likely to fit the cases, more or less roughly; if it does not, it is not. This installment moves upon the hypothesis that the orthodox analysis of Offer and Acceptance (even in the business field) in terms of two great divisions, unilaterals and bilaterals, does not well fit the fact-conditions. Into that it is proposed to inquire.

Since this paper proposes for consideration certain rules about Offer and Acceptance in the initiation of business bargains, and proposes to criticize certain "orthodox" rules as being either defective or false or unwise, it becomes necessary to make clear what is meant by "orthotox". I use the term perhaps arbitrarily, but not without a measure of justification. It refers to taught doctrine, and to taught doctrine which has for some decades been treated by teachers and the taught as stating "principle"; and which with very minor modifications has informed the teaching of all of us. Notably, there is a line of doctrine according to which, in a unilateral, three things coincide, and coincide precisely: to wit, acceptance, the bargained-for consideration, and the offeree's performance. ${ }^{1}$ Closely associated are the concepts that the offeror is master of his offer and is likely to ride it with a firm rein, and that almost the first question to ask about an offer is : what particular kind of acceptance did this offer call for; and especially: was it for a promise or was it for an act? The combination of these two lines is here referred to as "Langdellian", or as the "older orthodox" approach or doctrine, or as "classical". Corbin has recently suggested that an idea of similar status about consideration was "classic" (which Cardozo had termed it when he was showing its inadequacy) only because it had been announced by Holmes. In the cases, and in their results, suggested Corbin, the idea was not "classic". In this observation Corbin is entirely just to the cases, but not entirely just to the status of the doctrine. Those untruths and unwisdoms are, in the living usage of the word, "classical", which we have been rather generally taught to conceive as true and wise. It

1. I do not know what they teach in England. But cf. Pollock, Principlis of Contract (10th ed. 1936) 24.

2. Mr. Justice Cardozo and the Law of Contracts (1939) 48 YALE L. J. 426, 436, 39 CoL. L. Rev. 56, 66, 52 Harv. L. Rev. 408, 418. It is worth note that Cardozo, who was in law school in 1890 , felt there was "ancicnt rigor" to the bargain-detriment to the promisee. The traditions of case-law become ancient in flavor with great rapidity, once they take hold. Our ancestors brought with them England's common law, time immomorial goes back to Richard I, and contracts are by fundamental nature formed by promise for a promise or by promise for an act: it takes at most one generation of lcarning an oral tradition at the mother's knee to put the tradition on a substantial parity with other traditions, and often not even that. The Rand-McNally Mother Gonse includes amone: "the age-old rimes" some Edward Lear, and "I have seen you, little mouse," and "If all the world were apple pie." All that is needed is acceptance for one generation to malke this method of innovation work. Its use is ancient in law: Compare Pseudo-Isidor, the Partidas, the Leges Henrici, the "codifying" uniform acts, the Restatements. 
is of course the task of case-law judges and case-law scholars to get rid of them, and to substitute others which better fit what Corbin deals with as the system of our case-law-which means the going whole of caselaw in contradistinction to any intellectual "system" that is nol of our case-law, but only of our class-rooms.

The older orthodoxy of Offer and Acceptance (which was of cuurse not limited to the field of initiation of business bargains, in which it is here to be tested) has been suffering gradual modification and readjustment. But it maintains itself still in the minds even of many who accept various modifications, as being still "principle", from which "departures" are forced by justice or the cases or both. Such is the position basic to the Restatement. As an expression of "modern orthodor" dactrine, this paper will take that Restatement, with occasional passages from Williston and Thompson. For I have heard of no equally ambitious effort to provide an authenticated text of case-law doctrine to serve as a doxy: and its historical and conceptual connections with what I have called the older orthodoxy do not seem to call for documentation. ${ }^{3}$

3. Certain other points need note on the use of terms: (1) A duty is here said to be incurred, or an offer or promise to stick or an obligation to exist, or revocation to be barred, or a contract to have been made, when the situation has beceme such that a given "promisor" (envisaged as a possible defendant) can no longcr, on his (or their, or its) ocon motion, avoid or cscape court-fhreat for failure to perform as "promiced" or "agreed". The phrases listed are intended as synonyms. They do not suggest anything about the kind or degree of court-threat. They do not suggest that an action will ever lie against the offeror or promisor or other obligor concerned. They do not, in a word, anticipate anything as to whether the law of conditions may not excuse or discharge the obligor, or whether the law of mitigation or uncertainty of damages may not reduce recovery far below what the promise might seem to indicate, or whether the other garty's breach may not give to the obligor concerned any remedy that may eventuate. They indicate merely what is stated: retraction will no longer let this obligor escape courtthreat. All conditions, and all limitations on remedy are included in the obligation as part of the definition of its scope.

The distinctions well taken by Fuller and Perdue [The Reliance Interest is Contrast Damages (1936) 46 YALE L. J. 52, (1937) 46 YALE L. J. 373], and Mason [A Theory of Contract Sanctions (1938) 38 COL. L. Rev. 775], between "expectation-interest" ("contract-right") and "reliance-interest" ("right of reliance") are not material to this installment. They are, to the next, especially in discussion of the formation of non-agreementbased deals.

(2) The offers here discussed are promissory offers. As to them it becomes immaterial whether an offer is or is not "always a promise." Afy own preference goes with Corbin's, to think of a promise as something entailing assurance of the promisor's own future conduct; not merely entailing a legal result the whole machinery for which on the offeror's side is wholly set up by the offer. But that is not here of moment.

(3) "Promise" and "Offer" and "Agree" are used to cover the case in which words heard or read mean to the hearer or reader substantially what they meant to the spealier or writer. Cases of mistake and deception are not under consideration. Interpretative and constructive reading or addition by the courts is treated as part of the contractual obligation whose performance is "promised" or "agreed to." 
But it will here be urged that the challenges to the older orthodoxy found in the modern departures from it unmask the older "principles" as being no principles of case-law at all:

(1) The repeated qualifications and corrections already made in orthodox doctrine on Offer and Acceptance, especially with reference to "the unilateral", by their necessary implications destroy the fundamental frame of analysis and pseudo-principle to which they purport to be cutalificitions. If this be true, it is no waste of time to reexamine that frame, and by going through the already recognized qualifications placed upon it to show their implications when they are viewed in cummlation.

(2) The "recognized" qualifications have not been carried through in any consistency in the Restatement; this not even anent the partictular narrower points on which they have been recognized. The old frame of thought is no dead horse, in such instances; it is a horse which still kicks, evilly, in unexpected places. It is under real control only during moments of sustained and conscious attention to the need for controlling or disregarding it. ${ }^{4}$

(3) Therefore some type of synthesis of the particular work already accomplished must be begun, if we are to see what that work really means. If there is indeed any unity of case-law doctrine to be had in the Contract field, the hope of finding it lies in a search which begins with recognizing as part of the foundation those cases which have forced so much explicit modification of an older basic analysis now conceded to be defective in part.

(4) The very qualifications made to correct a faulty basic analysis tend to be drawn off accuracy by the deflection of issue-seeing and issuestating which the faulty basic analysis itself almost necessarily produces in folk who (like all of us) have grown up in it. We pose isstes badly,

4. The major single contribution of realistic technique, and one available to each branch of legal juridical method, is insistence on sustained endeavor to malie corrective or creative effort conscious and explicit, to accumulate the efforts, to check today's insight against yesterday's for mutual correction, and, in a word, to advance the arts of legal work from the intuitive or haphazard a little toward the communicable and teachable and reckonable: to advance the average level of the arts in question. Some Realism About Realism-Responding to Dean Pound (1931) 44 Hanv. L. Rev. 1232, 1237, n. 67: Thranqh Title to Contract in 3 Law-A Century of Progress (1937) 80, n.24-(1938) N. Y. U. L. Q. REv. 117, n. 24-which latter paper, together with The Rule of Law in Our Casc Law of Contract (1938) 47 YALE L. J. 1243, and the prior instailment of this paper [(1938) 48 YALE L. J. 1] may serve as illustrations of what is meant. As to study of the jutlicial process, there is beginning some recognition of this contribution of realistic techuiculus, Pound, Fifty Years of Jurisprudence (1938) 51 HARv. L. REv. 777, $796 \mathrm{ff}$. Kennedy, Realism-What Next? II (1939) \& FordaAM L. Rev. 45, 50, n. 16, appreciates also the possibilities in regard to more accurately seeing the state of prevailing law. The contris bution of the technique goes much further; it holds for the arts of advocacy, counselling, legislation, and the more "legal" phases of administration: in a word for all the legal engineering arts. 
if we see problems in blur; we answer badly, if issues are badly posed. This has happened too often in the very attempts to cure defects in the older orthodox doctrine of Offer and Acceptance.

(5) The student, and especially the neophyte, is entitled to as simple, as understandable, as horse-sense, and as easily approachable body of legal doctrine as the cases can be made to yield. Yet it is my belief that the classroom lags in this matter of Offer and Acceptance materially behind the more advanced state of present orthodox theory. It is my belief that the beginning student meets the Langdellian unilateral in materially balder form, as one of his two basic Contracts concepts, than one finds in convenient fat type, for instance, in the Restatement. It is my belief that the student is led to deal with promises, for instance, in formation of contract, pretty much as such, and not with a constant eye on the agreement, the notification, the expectation, the reliance aspects, and on the ultimate performance, and the ultimate remedy, and such other matters, of which writers of many volumes or sections can at their leisure take more adequate account. It is my belief that offeror's and offeree's "promises" are treated in the classroom as if they were alike.

If the world of law is thus at its very creation in a student's mind created in divisions and in concepts which falsify the facts of law, the student is helpless. The false concepts give him his only eyes to see that legal world, his only words to describe it. All later effort at qualification leaves it permanently distorted to him.

Enough of apologetics. If this means the flogging of dead horses, flogged they shall be.

\section{Only Business Contracts; Only Their Initution}

This installment is not a discussion of Offer and Acceptance in the large. Its scope is limited to the initiation of business deals which result in the type of legal obligation we know as Contract. Of course, if the discussion succeeds in persuading that the orthodox approach to Offer and Acceptance is unsatisfactory in regard to the initiation of business deals, the conclusion would be close that that orthodox approach is in need of material remodelling, if only because so many of the casts to which it purports to apply involve the initiation of business deals. But the proposed modifications have been built out of and for that narrower field, not for the field of Offer and Acceptance at large. This has seemed to me a necessary procedure.

First, as to the initiation of business deals, as distinct from their readjustment or continuance or cancellation. In the initiation of business deals the more fruitful conceptual arrangement to deal with the material makes acceptance-in-law and consideration coincide, in regard to any promise made by an offeror. Cases do not occur to me in which an initiating offeror is barred from effective revocation, in which one cannot 
put a finger upon some overt phenomenon which serves conveniently to satisfy both requirements. But in the later history of a contract that hypothesis is troublesome. A debt incurred, and then barred by bankruptcy or limitations, needs no overt action by the promisee to malie a promise to pay it irrevocable. An indorser discharged by failite of notice can "waive" by saying so, and then cannot withdraw. Despite the Restatement's effort to integrate "waiver" having obligatory effect with the bargain theory of consideration ${ }^{5}$ (instead of with Informal Promises Without Consideration) the courts are likely to go on allowing reacljustments of going deals to be made by procedures which are neither law nor sense when applied to initiation of bargains; and they otght to. The factual role of silence in acceptance of a proposed minor rendjustment of a construction contract is, for example, very different from the role of silence in initiating the same contract; and the law may reflect the difference. The problems of hardship and hold-up under the preexisting duty rule, forcing a discrimination between clear expression of agreement and the consideration required, have no proper counterpart in the field of initiation. Now it is not my position either that there is a single general case-law of Offer and Acceptance or that there is not such a single general case-law. It is my position that the way to find out is to examine situations one by one, picking the situations in the hope of getting them significantly large and at the same time significantly unified, to see what the case law is in such situations, and to see then whether and how far generalization is safe. Thus far, I am persuaded that in initiation of business deals one can safely take the prollems of acceptance and of consideration as coinciding; and if so, it would seem peculiar if the coincidence did not affect the law of each. But even more, I suspect that the reaching of agreement is watched for with a nicer eye, and is required to be shown with more precision, when parties are still meditating on whether to deal than when they are already engaged in dealing; so that concentration upon the initiation of business deals ought to provide a very useful type of transaction and of ruling: against which to measure any variations as one moves into wider synthesis. One line of such variations which I suspect to exist lies in the formation of a succession of individual deals within the framework of a going relation; the Offer and Acceptance doctrine of the "course of dealing" has yet to be worked into clarity.

These are reasons for attempting here to concentrate upon initiation of business deals. One may add another reason: initiation has becn in fact the ideal picture against which conscious thought about Offer and Acceptance has been projected. It is well to study the ideal picture first against the facts to which it is best fitted.

5. $\$ 279$. 
Somewhat the same line of reasoning, but in more vigorous form, underlies the concentration here upon business deals. Again, they have provided the ideal picture against which current doctrine plays. They also provide the overwhelming percentage of instances in life. Whatever facts provide in the way of suggestion of norm should thus flow in all cases from the business cases. Or so one might lightly think. So to think would however be to overlook, at least for the family cases, the fact that judges have an experience with family matters which is earlier and more intimate than any understanding of business. And the business cases prove not to be wholly adequate guides to the family cases. ${ }^{\circ}$ $A$ fortior $i$ the family cases are not adequate guides to the business cases. ${ }^{7}$ Until the two have been studied, each group by itself, synthesis must wait. What is already indicated is that it is not safe to reason about business cases from cases in which an uncle became interested in having his nephew see Europe, go to Yale, abstain from nicotine, or christen his infant heir "Alvardus Torrington, III." And it may even be urged that safe conclusions as to business cases of the more ordinary variety cannot be derived from what courts or scholars rule about the idiosyncratic desires of one $A$ to see one $B$ climb a fifty-foot greased flagpole or push a peanut across the Brooklyn Bridge. This paper will not even reason from such cases as that of a book collector who is farored as a Christmas present with all but one of the volumes for which he has offered a peculiar price. It is not suggested that a court in solving such problems might not be seeking to apply a principle applicable equally to business cases; nor is it suggested that the solution reached for such problems by a court might not have repercussions in business cases. The position taken is this: The influence of the facts relative to the influence of the normally applicable rule increases roughly with the square of the peculiarity of the facts. Therefore the decision of a case really peculiar on its facts is never a safe guide to the decision of normal cases ahich have not yet been decided under its rule. But if a peculiar case is decided in true accordance with a rule in use in normal cases, that is excellent

6. Compare Havighurst, Services in the Home-A Study of Contract Concepis in Domestic Relations (1932) 41 YaLE L. J. 386; Shattuck, Gratuitous Promises-A New Writ? (1937) $35 \mathrm{MI}$ ICH. L. REv. 908. The law of voidable preferences would no less reward study from this angle.

7. Would a careful counsellor advise a business client in a business transaction to rely on DeCicco v. Schweizer, 221 N. Y. 431, 117 N. E 807 (1917), or Thomas v. Thomas, 2 Q. B. 851 (1842), or Devecmon v. Shaw, 69 MId. 199, 14 Atl. 464 (1883), or Orr v. Orr, 181 Ill. App. 148 (1913)? Of course there are business cases which no careful counsellor would rely on, and those mentioned ought not to be relied on in counselling even about family matters. But the unreliable business eases are not thicls as daisies; and the family cases mentioned would give an adrocate in a family case a pretty solid footing. But a counsellor wants an utterly solid footing. 
indication of the living power of that normal rule: it has overcome even tough and troublesome facts. ${ }^{8}$

This instalment deals, then, with the initiation of business deals in what are conceived to be rather common situations.

\section{The Theoretical or Classroom Dichotony-And Life}

It will be recalled that the theoretical or classical or dialectical or classroom unilateral which is "the other type" of contract finds its older doctrinal essence not in the fact that "an act"-or more properly "the" requested act"- -will bar revocation, but in that only that requested "act" will serve to bar revocation. For the classical or classroom unilateral does not rest in first instance on a theory about agreement. In first instance it rests upon a theory of consideration. And classical theory is wise in holding that consideration and acceptance coincide. But classical theory rests also upon a particular theory of consideration. It rests upon the particular theory that no offeror's promise can stick in law until the particular bargained-for equivalent has been "given" accurately and completely by the offeree. Indeed, it is because completing the equivalent was conceived as necessary to close the "bargain" that it was also seen as necessary to satisfy what becomes in unilaterals a second and secondary theoretical requisite of "Contract", to wit, the re(puisite that Contract effective in law must be grounded on "mutual assent". And it is because a bargainor is in the classical ideology the utter master of his bargain that an offeror is conceived as the utter master of his offer. He being thus the master, he can dictate that even langtage of express assent by the offeree shall not amount to assent, in law. So, $a$ fortiori, he can dictate that even though action by his offeree is intelligible only as referring to the offer and as expressing agreement to the bargain proposed, yet that action shall be regarded as legally nugatory on the matter of "expressing assent". This is because such matters do not satisfy that consideration requirement which is laid down by the offeror's supposed insistence upon "the act" as the only thing for which he is "bargaining his promise".

Now this theory that agreement coincides in such precision with the consideration-requirement of an offeror's legal obligation patently divorces the resulting supposed "law" of agreement from the course of actual agreeing. What looks like expression of agreement-in-fact by the offeree is not effective as agreement-in-law; and what does not look like expression of agreement-in-fact may be effective as agreement-in-law. It is conceivable that this may be a healthy condition of doctrine in any world where offerors bargain to get red flags hung out across the lake in heavy

8. In a word, rules and principles announced in or concerning case-law must be regarded as containing an ad hoc element; only the test reveals whether and how far the phrasing bears weight. 
fogs, but in the world of American business dealings it is an embarrassing condition of doctrine.

When the case is one of "promise for a promise," orthodox doctrine again makes the requirements of consideration and assent coincide, performance dropping out of the picture of formation. But there is a shift of emphasis. In the "promise for promise" cases it is not consideration which sets the measure for assent by the offeree; it is assent by the offeree which sets the measure for consideration. So that consideration thinking does not, in the ordinary case, interfere with getting the facts straightened out: on the contrary, in the "bilateral" situation horse-sense about agreeing has forced such modification of the orthodox "detriment" theory of consideration as has proved necessary to make room for bilateral executory obligation.

But the dominance of the consideration concept as a bargain concept remains in the net picture of Offer and Acceptance under orthodox doctrine. For he who looks for the bargained-for equivalent comes under a strong psychological urge, doubly hard to escape consistently because it is not conscious. That urge is to look for a single and exclusize bargained-for equivalent, and so for a single and exclusiz'e line of legally adequate expression of acceptance. Hence, the question recurs in the classrooms of the country: "Did he ask for a promise or for an actfor an act or for a promise?"-with the eternal suggestion that only one is normally asked for, and that only the one will do. This makes, as we all know, for superb classroom theatrics; I know of none which have ever given me personally equal fun. But the fun comes at a high cost to students' real understanding. ${ }^{\text {? }}$

For this matter of angle and attitude of approach is of importance. It goes so very far to determine what one gets out of his doctrine. When one is faced with a business case on Offer and Acceptance, one can attack it from either of two poles, or from any point between.

A. At the one pole is the approach which is suggested and even urged, psychologically, by thinking in terms of the Great Dichotomy. That approach tacitly but effectively sets up a presumption that the line of possible acceptance has been prescribed, and as prescribed is single:

Which particular and exclusive line of acceptable acceptance has the offer's master prescribed? Of course, if he has made clear that some alternative is available, then such alternative is also available.

The effect of this is what the irreverent might describe as preventing a contract for the parties. ${ }^{10}$

9. There is a fine flagpole outside my classroom vindow, with a golden crown on top, and something very lovely went out of my life two years ago when the cases finally compelled me to stop revoking with the student almost up to the crown.

10. Corbin, Offer and Acceptance Selected Reaprwas (1931) 170, 176: “. . . the judge who is most certain to do injustice is the pedant who holds contractors to meticulous 
B. At the other pole is the approach which common horse sunse wotuld urge, on business facts. It does not look for any single line of acceptance. It takes as a base-line that a business offer is made (by a reasonable person in reasonable circumstances) in the hope of getting a deal closed, and indeed with the purpose of inducing a deal to be closed and of making it reasonably easy to close, so far as manner of acceptance goes. This approach therefore argues that reasonable interpretation must see as acceptable to the offeror any line of normal acceptance which there is not plain reason for excluding-simply because offers are reasontably read to invite deals, and are reasonably read not to be legal trickery. If there is question as to whether a deal, a final closing, is being invited, and even urged, that question goes to whether we have a definitive offer at all. But if there is once decided to be a definitive offer, then horse sense gets up an explicit rule of construction that any reasonable way of expressing agreement will be effective, in the absence of violent negation :

An offer is to be read, if possible, as acceptable by the offeree's expressing unambiguous agreement in any manner which an offeror might reasonably anticipate as a reasonable manner in the circtum. stance. Of course, if the circumstance was queer enough, or the offeror was queer enough, to lay down some single manner as the only admissible manner, and if such a queer result was made adequately clear to the offeree, then that will limit the otherwise available modes of acceptance-in-law.

It is important to observe that classical orthodox doctrine, taken simply as explicit doctrine, prescribes approach neither from the one of these poles nor from the other. But neither, until some line of approach is selected-a wise one or an unwise one, a conscious one or a tacit, hidden one-does classical orthodox doctrine give an answer to that more ordinary case in which the offeror has not said: "Only by sky-writing YES over South Brooklyn can you accept this." Explicit orthodox doctrine, as such, leaves it open to shift the line of approach all the way

accuracy in the usage of words and in the construction of sentences." At 195: "Instead of being expressly limited, the offer may prescribe no mode of acceptance whatsocver. . . In this case the offeree may accept in any manner that the law deems to be reasonable under the circumstances." (my italics). Contrast Restatenent $\$ 29$ : "An offer may invite an acceptance to be made by merely an affirmative answer, or by performing or refraining from performing a specified act, or may contain a choice of terms from zelich the offeree is given the power to make a selection in his acceptance." (my italies). This listing of specified modes first, and suggestion that a choice has to be contained in terms, is not accidental. Compare the "rather than" in $\$ 31$; the phrasing of $\$ 24$; but especially $\$ 52$, excluding any suggestion that an expression of agreement will suffice when a performance is requested unless the operation of such expression is explicitly negated. For an excellent indication of the orthodox attitude and approach see Williston's Wald's PoLLock (3d ed. 1906) 34, n. 39, the significant part of which is the assumption that the judges there differed with were talking of offers not acceptable by expression of agreement, merely because those offers aicre acceptable by performance. 
from the one pole to the other, and so to shift the answer, without any disturbance of the doctrinal base at all. The shift is opposed not by logic, but by psychological factors quite irrelevant to the contents of the supposed principles concerned. Nonetheless, opposition to such a shift there is; for as the doctrine has come to be taught and used, the approach set forth under (B) has come to seem strange, unfamiliar, even quteer. Indeed, should such an approach ever become generally accepted as the standard way of going at Offer and Acceptance in regard to business bargaining, then half of what this installment aims for wotld be accomplished; and accomplished with no need for disrupting the uldur classruom frame of principle at all. Neantime the Great Dichutumy cuntinuts in classroom practice to divide the supposed problems of formation "fundamentally", as a railroad track divides a town, into two mutually exclusive categories, "unilateral" and "bilateral". But with this difference: that the classical dichotomy in Offer and Acceptance has little relation to the living fact of the business contracting which it divides. NLeantime, and moreover, if we are to, if we indeed have to, use what are in effect rules of presumption and construction in order to bring curr ductrine to bear on the general run of cases, then the rules we use need to be made explicit rules, in order that they may be better used-and better tested.

\section{The Promissory OfFer}

The living facts are best approached by way of what we have come to call the bilateral situation, that of a deal encisaging postponed future performance on both sides, and mutual obligation. I pick it up first because it is the most frequent type of business contracting likely to raise legal problems. I pick it up first also because to see it clearly is to set the stage for understanding the case-law of other situations, in which it is reasonable for an offeree to move directly into performance.

In the bilateral situation the first and outstanding fact of life is that outside of lunatic asylums real people do not in good faith offer "a promise for a promise". What decent business men (when nut ghosthaunting a first year class-room under the alias of $A$ or $B$ ) are constantly doing is a thing materially more complex but vastly more sensible. And all scholars and all courts know this; and when their minds are on consideration or conditions or damages instead of on Offer and Acceptance, scholars and courts show they know it. What the business men do is to offer (mostly on behalf of some group or outfit) not words, but other things, by means of saying words. The term "promise" is ambiguous as to whether it means words, or their results, or both together; but even in this last sense, it is far from exhausting the substance of the offer. Business men offer, together with the promising and as its consequence, a continuing expectation and sense of security-an assurance 
in result as well as in expression-which has immediate and contintuing value in itself. This assurance is offered, to be relied on; and after the deal is "on", it is not to be withdrawn." Its value exists, however, almost wholly because the assurance foreshadows the second thing which is also and simultaneously offered. That second thing is an tiltimate actual performance of roughly indicated character which is to occur in due course. And the proper occurrence of this second thing is the real bait of the proffered bargain, and is the most vital piece of bargainequivalent in the picture. These two things, which are only meditated by the promising, make up the essence of every decent business offer. ${ }^{12}$ It is their absence which makes the class-room banter lack the character of offer. It is the absence of the second which makes the kiting of checks approach the fraudulent in character, and leads to criminal prosecution for the passing of checks foredoomed to bounce. Whether, as a third element in what is offered, there is also a legal obligation which on acceptance is to rope the offeror, is not always clear as an interpretation of the factual thinking and understanding of the business offeror and offere. But I incline to think that typically that third element is in the picture, too; just as I incline to think-save in quite abnormal situations-that legal obligation plays definite third fiddle to assurance and sense of security, and to performance itself. ${ }^{13}$ By this I do not mean that some

11. Indeed, in business, offers are effectively relied on, and are often supposcd to be firm, though not so stated. German law recognizes this by making revocability require expression; ours refuses to, even when irrevocability is specified. Enough American offers are expressed as "firm" and enough German ones as "freibleibend" to make clear that need exists to make an offer in either way.

12. In various ways various writers express the "more than words" in a promise: the continuing relation, the anticipation of performance-in-actuality. The Restatement makes a promise "an undertaking either that something shall happen, or that something shall not happen, in the future" (\$2), and the Comment makes "promise" include "the moral duty to make good the assurance by performance." Corbin emphasizes the creation of justified expectations. Gardner speaks of a promise as conferring power over the future. Pound speaks of transactions which enter into a man's substance. Legal concepts like failure of consideration or constructive condition of exchange reek of the need for actual performance-as does the "holding the contract open" of anticipatory would-be breach, or the idea of inadequacy of damages.

The fullest and best description I have seen in print of the situation against which the law of Offer and Acceptance ought to be seen is Fuller and Perdue, The Reliancc Interest in Contract Damages, I (1936) 46 YaLE L. J. 52, 57-71. The fact that the focus of interest there is the extent of remedy makes it peculiarly enlightening: Offer and Acceptance doctrine has suffered by isolation and insulation.

13. In some types of agreement the nominal performance is indecd not expected: thus in some types of future trading, looking only or mainly toward settlement of differences. But even so, performance is expected of the true subject-matter: the payment of the difference, and that performance is the nub of the deal. Such transactions occur even when legally unenforceable. As a type, such agreements are parasitic and specialized offshoots of true agreements to sell and deliver; but as individual deals their substance is simply other than their form. As, in regard to legal obligation, is a contract 
legal effect of an offer may not often be present in a layman's mind as he makes or receives or accepts an offer. I mean that when legal effect is in his mind, it only in abnormal situations appears to him in its lawyergarb of "legal obligation", semi-precise as to what it will not afford him, envisaged as all hedged about and limited in its scope and in its certainty and adequacy of remedy. When the ignorant layman wants "one dollar" recited "to make it legal", his mind is on making "it" stick as done or as to be done. When the more experienced layman wants it to be a legal obligation, his mind, no less, is on assuring ferformance; even deliberate arranging for it to be "legal" remains a subsidiary thing; it is a means of buttressing into unmistakeability the two factual phases of an offer: the sense of assuredness, and the performance to come. For when the contingency of non-performance really even begins to loom at the time of contracting, the business man goes after not mere legality of obligation, but legally enforceable "sccurity" or "collateral". ${ }^{4}$

Thus, offered by means of a promising, are an expectation and security therein, an ultimate juice of real performance, and a legal dbligation which is conceived as a subsidiary to make both more solid.

And if an offeror always received in return a precisely similar combination and sequence, we could call the closing of agreement "promise for promise", and let it go at that. Nor should we be misled by the simplified phrasing. The reason why it pays to try to spell out the whole of an offer's content, even so roughly as above, is that the lawyer's problems, in formation and after, arise when what the offeror gets in return fails to conform exactly to the pattern of what has been offered. Contemplated, in the offer for prospective mutual obligation, such an exact correspondence may be. But what is contemplated is not always what occurs; nor is it what is effective in law. And it is well, very early, to observe than an offeror is not the full and untrammeled master of the effects of his offering. He may be master of his language, but it is the courts and their law who are masters of the legal effects of that language. This is a point which Williston makes in regard to whether a legal obligation must be contemplated by an offeror ;5 it is a point he makes again in regard to the use by mistake of expressions which mis-

that a third party will faithfully perform; the legal obligation is to reimburse if he does not.

14. In certain types of case, notably those affecting associations, the lay mind turns to specific performance or injunction: "They're a bunch of chiselers; can you fix it so they have to?" So, in a labor bargain, with the contract not to strilie; so oiten in organizing a trade association or a cooperative. The point is that what is sought is not legal obligation, but again a road to insuring performance.

15. 1 WIILISTON aNd Thourpson (1937) $\$ 21$ : The common law "does not require any positize intention to create a legal obligation as an element of contract." "The law, not the parties, fixes the requirements of a legal obligation." Similarly, re reducing to writing, in $\$ 28 \mathrm{~A}$. 
lead an offeree. ${ }^{16}$ It is a point which he makes in regard to the construction of protective conditions not included in the language of an offer which happens to have resulted in a contract. ${ }^{17}$ It is a point which he does not make in regard, for instance, to offers which have not yet so resulted, and whose language may appear to call for "an act" as acceptance, or which Williston sees as apparently calling for "a promise" as acceptance. ${ }^{18}$ The point needs making in all these cases equally, or else in none of them. The decisions, as between offeror and offeree, have tended strongly to take the line of reasonable reading, in each of the problems.

\section{Exit "Promise for Promise": Counter-Promise v. Expression of Agreenient}

Meantime, pursuant to the offer, the offeree takes same action, and the offeror changes his mind, and says so. The problem will be: what action, and how much action, will be needed to bar such revocation. The classical answer is that after a definitive offer the making of the contemplated counter-promise is enough, and that it is required. And in face to face dealings which do not involve a writing, that answer would seem to be accurate. But it is of course as obvious as it is familiar that in such a case the offeror's promise sticks before he has more than begun to get what in any intelligible sense he really "asked for". A promise he has; an expectation has been aroused in him and an assurance created; a legal obligation has been incurred by the promise. Wholly in the future, however, lies the continuance of that expectation and assurance (with all that means for anticipatory repudiation); in the future lies also the meat of the nut, the desired performance (with all that means for the law of conditions). Meanwhile, the continuance of the offeree's legal obligation may be conditioned on extensive and expensive further action by the offeror, and its content and scope may depend heavily on rules

16. Id. at $\$ 35 ; c f . \S 89$.

17. See Cook's discussion in (1939) 33 IL.. L. Rev. 497.

18. E.g., Williston AND Thospson (1937) $\S 60 \mathrm{~B}$ : "It seems undeniable that an offeror may propose a unilateral contract which shall require as consideration not the mere tender of an act, but such actual performance as can be accomplished only with the cooperation of the offeror." (my italics). This statement does not make sense, since a definitive offer is capable of acceptance by the offeree without further action by the offeror. The proposal referred to is thus a piece of preliminary negotiation. But that it could be written shows how far the conception of the offer as "master of the offer" can carry. Cf. $\$ 72 \mathrm{ff}$., where, as elsewhere, discrepancies in the cases are covered in by "interpretation." $C$. also $\$ 70$; where, however, and in $\$ 71$, an offeree's contractual obligation without any promise is carefully recognized. With this, the definition of contract as promise goes by the board. Indeed, it goes pretty well by the board at the outset, when the ambiguous term "undertaking" is introduced. But "promise" does not therefore lose its connotations in the further discussion. 
of damage and mitigation. Yet the offeror's obligation sticlss, as against any attempt to withdraw from it.

Indeed if the deal be not face to face, much less is needed, to make it stick. An affirmative answer, a so-called "counter-promise" by letter, will operate not when received, but ailhin mailed. It does not create expectation when mailed. All that the offeror has gotten when his own ofter sticks is a legal obligation resting on the offeree-an obligation of which the offeror does not even know, and whose value to him, as we have seen, is secondary. A legal obligation alone is not what he wants or wanted. Buying law-suits is junk-yard business. Yet this legal obligation is what the offeror gets at the moment that he is stuck with his own obligation - that, coupled with a very real high probability (of which he does not know) that he will shortly be informed of it, and thus acquire an opportumity to start expecting and relying. Our case-law is strong against taking the offeree's will for his deed; but it will joyously take his deed for his communication. Williston and Thompson discuss this situation with care, show that without effectuated communication there can be no promise in any meaningful sense, and make clear that the courts are all but unanimous in finding acceptance before any promise has necurred. ${ }^{19}$ Since the offeree cannot escape obligation even by withdrawing the letter from the mails, it is clear that mutual obligation is incurred before there has been a second promise; and since later loss of the accepting letter makes no difference, it is clear that the second "promise" is not given effect, so to speak, merely as of the moment when it is fired rather than as of when it hits its mark, as a matter of dating; but that it is the soing off, and not the hitting, which is what matters. ${ }^{20}$

Williston and Thompson properly observe that the great body of contracts formed by mail (or telegraph) are mutual obligations $;^{: 1}$ one can add that apart from delivery of newspapers and groceries at the door, on credit, and the like petty transactions, this may well be thought to

19. $\$ \$ 1 \mathrm{ff}$; also $\$ 70$.

20. Washburn v. Fletcher, 42 Wis. 152 (1S77) ; Mercer Elec. MIfg. Co. v. Connceticut Elec. MIfg. Co., 87 Conn. 691, $\$ 9$ Atl. 909 (1914). There seems to be no doubt about this if the mail is a mode of acceptance reasonably within contemplation. WIILssos $A: 0$ THoxrpson (1937) § 83. And I take the steady line of growth to be one of enlarging, and removing doubts from, the availability of the mail as a proper medium. To the extent that any case holds that an "unauthorized" mailing will not bar revecation by an offeror, when there was no such condition as receipt of notice of agreement, that case is at odds with the analysis here proposed. Even a mis-addressed letter must. it scems to me, be regarded in sense as an unambiguous overt expression of agreement. It is, huwever, no less clearly an improper device for notification-a thought which gres sume distance to clear up the problems of $\$ \$ \$ 4$ and $\$ 5$ of Wrumstox Ano Trosrson:. Case-discussion must be laid over until the sender's recapture of a letter and the insurer's assumption of obligation without a letter can be brought to bear-which requires first that the "bath or neither" pseudo-principle be cleared out of the way.

21. $\S 81$. 
account for a third or a half of the business contracts made daily or annually in these United States. Williston and Thompson suggest, as to this overwhelmingly important phase of general contract law, that the offeree's overt manifestation of assent, or outward indication of assent has been what moves the courts to raise contractual obligation when there has been no second promise. ${ }^{22}$

This is sound suggestion, so sound as to call for development. Business men do not think much in terms of giving or getting counter-promises, as such. They think in terms of giving and getting agreement by an offeree. Agreement, or agreeing, includes assent: getting agreement includes also getting assurance, getting commitment for the future. Agreement is a thing to be relied on. Wherever, then, a businessman expects to arrange his affairs with an eye to an outstanding offer if that offer leads to a deal, he needs in due and proper course to get news of assent, and above all niews that gives him assurance for the future. This is quite clear. It is what underlies the emphasis on the need for a counter-promise. It is clear that it would be hardship on any offeror to hold him legally responsible on an offer unless he has received newes that the deal is on-and this irrespective of any quantity of assent and reliance on the part of the offeree. What is not at all clear, however, is that there is any occasion in life, or need be any occasion in law, for forcing the expression of assent to be lumped with the giving of assurance into a single action or set of words. There are two jobs to be done: the overt expression of assent and indeed of active agreement; and the giving of news thereof which will communicate assurance: Only the latter has any necessary relation to promising; the former can be done adequately by an unambiguots beginning of the work. And since commonly both are to be done, and done promptly, the offereree's business job of effective formation is not over until he has seen to both. A letter of acceptance, when mailed, is an effort to see to both at once.

But if overt expression of active agreement occurs before efforts at notification, a question immediately opens as to whether that overt expression by action will not be of itself enough to bar revocation by the offeror from that time forward-providing only it be followed in due season by the proper effort at notification. The line of problem is one which recurs eternally: if two facts of importance have been treated as coincident, and as having a particular legal effort when coincident, and proceed to occur separately, then: (1) Are we to take either as being the only significant one? And if so, which?; or (2) Are we to reexamine the situation, and give each fact its due weight and its specialized legal effect? And if so, how?

Presented with this problem, when speaking promissory words and hearing them had previously coincided, but negotiations at a distance

22. Ibid. 
began to force discrimination between the two, our courts grew slowly firm in the position that the wilole legal effect lay in the offeree's effort to communicate, properly made. Into that choice, and into the conception of what would be an adequate effort, went the whole factual weight of an effective technical system of communication. As between hardship on the offeror which is really tough, and hardship on the offeree which would be even tougher, ${ }^{23}$ the vital reason for throwing the hardship of an odd delayed or lost letter upon the offeror remains this: the offerce is already relying, with the best reason in the world, on the deal being on; the offeror is only holding things open; and, in view of the efficiency of communication facilities, we can protect the offerees in all these deals at the price of hardship on offerors in very few of them.

Now this same line of policy and of feeling moves into play when the facts raise the question of a discrimination between expression of agreement and notification thereof. If the offeree begins action in such unambiguous fashion as to be an overt expression of active agreement, he has begun relying. The offeror is still holding matters in abeyance. Until the proper time expires for sending nea's of acceptance, there is no hardship on the offeror if he discovers that acceptance has occurred before he made his revocation effective. He never knows, anyhow, when acceptance has occurred; and he has indicated how long he was willing to wait for news. However, the overt expression of the offeree has not done the second job, that of despatching notification. Within the time, he has this still to do: notification, not that "We hereby accept," but

23. For regarding the hardship of an opposing rule as even tougher on the offeree there are two good reasons. In the first place, the ingrained usage of business is to answer letters which look toward deals, but the usage is not so clear about aclnowledging letters which close deals. The absence of an answer to a letter of offer is much more certain to lead to inquiry than is the absence of an answer to a letter of acceptance, so that the party bitten by the mischance has under our rule a greater likelihood of being aware of uncertainty and of speedily discovering his difficulty. This goes to the hazards of communication. In the second place, and regarding the time of closing, the risl: of the market shifting against the offeror, unbalanced by the chance of gain if it shifts in his favor, rests under our law on the offeror during one transmission period plus time for answer-subject to effective telegraphic or telephone communication. He wants the deal; he takes that risk. But to fail to close the deal as against the offeree until the letter of agreement arrives is to extend that unbalanced risk of the market without observable reason. We have seen that it will be rough on the offeree if he is not permitted to rely on having obligated the offeror; but it will be even rougher on the offeror if he is obligated whereas the offeree, at the offeree's option, is not-ahen there is no reason for the inequality. It is not a question of principle that both must be bound, or neither; it is a question of principle that there must be a good rcasen for "binding" one while leaving the other free. This is why the cases suggesting power in the ofieree of effective recapture or telegraphic annulment of his letter of acceptance are to be vieved as unwise in their possible application to deals of mutual obligation; and as untrustworthy as well. Of course the offeree's counsel can offer a rule of thumb: try it and see; it can't be worse than letting the letter go through. That is no case-law rule for judges. 
that "We have accepted and we are glad to state that your order is already well along." If he despatches the notice in due time, good. Otherwise, he loses his right against the offeror. This is business; it is sense; it will be surprising if it does not prove to be at least majority case-law. As a conceptual frame-work, it also irons out into one set of comfortable systematics the problems of acceptance by mail and those of agrecing by overt action, and squares both, as contracts of mutual obligation, with the intelligent rule announced in Bishop $v$. Eaton, requiring due diligence to notify an offeror after performance under the offeror's guaranty. ${ }^{44}$ That is a gain for simplicity. At the same time, the essential character of due diligence to notify the offeror that he may and must arrange to regard the deal as on keeps a deserved spot light on all agreement-based deals. ${ }^{25}$

Shall we find the decisions fitting such a pattern?

The background of case-law thinking gives some ground for hope that we may. For our judges views about contracting have by no means cut free from the traditional base-line of a century back, from the notion that the essential basis of contracting is Agrecment. The courts' analysis has not been over-refined nor over-sustained. They have followed, and largely follow still, the case-law tradition of fusing and confusing law with fact, as also of fusing and confusing diverse legal relations and results. A contract used to be "an agreement which was legally enforceable"; then it was an "executory contract". Or it was an "agreement with legal effect"-in which case it could be an "executed contract" or an "executory one", or one which like the "contract of sale" might be executed as and when made. But the operative facts were to be facts of agreement. Into this line of thinking broke the line of thinking in terms of a contract as involving not agreement in first instance, but prowise -or "a set of promises." This the Restatement accepts. But the Restatement still stands firm in further keeping law fused with fact: a contract "is a promise" (or a set of promises) legally enforceable. "Corbin's

24. 161 Mass. 496, 37 N. E. 655 (1894). RestATEMENT, \$ 56 , gencralizes from guaranty to all unilaterals "if the offeror has no adequate means of ascertaininge with reasonable promptness and certainty that the act or forbearance has been given." This is of course stated as an exception upon the general rule that no notice is required "where forbearance or an act other than a promise is requested as the consideration." This needs to come out of the backhand, and out of the dichotomy, and to become a rule about the need for notification in all contracts, at peril of the offeree, with the detail devoted to canvassing "due diligence" more carefully, especially on the matter of time. Sce next installment.

25. One exceedingly confused field into which this analysis brings clarity of issue is that of principals dealing with "brokers" in central markets, where the courts now wobble between "agency" and "sale," and between "acceptance by action" and "acceptance by communication."

26. \$2. Cook points out that Williston cannot stay within this definition. Of course he cannot: " . . . the courts so frequently construct under the guise of mere interpreta- 
sounder and keener insight on this latter point the Restatement rejected. Corbin saw in Contract not a promise (which is a term of fact), but a type of legal obligation which normally rests on promise or promises as part of its operative facts. ${ }^{2 \pi}$ And it will be noted that acceptance of Corbin's concept makes it easy and simple, wherever there may be need, to enlarge the description of the operative facts which give rise to the given type of legal obligation; whereas acceptance of the Restatement's concept makes that hard.

Now the shift of focus and phrasing from the "agreement" of judicial tradition to the "promise" of modern writers has had an important value for theory: for it has invited attention to those promises which do not inrolve agreeing at all, and which yet become legally enforceable; so much so that in the Restatement ten sections ( 85 through 94) could be devoted to them under what may be called the almost revolutionary title: "Informal Contracts Without Assent or Considcration." But that same shift from agreement to promise, when applied to contracts of mutual obligation (which are not discussed anywhere in Sections 85-94). has led to less happy results. For if you believe that you must find a "set of promises" to get a mutual contract-or to get either half of a contemplated nutual contract-then you will do two undesirable things. The first is, when you see that there just has to be a contract, that you will "see" or "find" a "promise" where there is no promise-as when a projected prumise is put into writing and mailed. This bothers your description of what you are talking about; because you must either reconcile or else insulate these non-promise cases; and to insulate and then forget them makes your systematics unclear and inaccurate. Though it leaves you with good enough results in the particular body of cases, it leaves you with misleading premises for thinking about any other cases. ${ }^{23}$ Thus the sucond

tion." Corbin, Conditions in the Law of Contract, Serected Resnmes (1931) 871, \$73, (1919) 28 Y ALE L. J. 739, 741.

27. Corbin, op. cit. supra note 10, at 170: "the legal relatiuns between nersulb arising from a voluntary expression of intention, and including at least one primary right in personam, actual or potential, with its corresponding duty." Ibid.: "the relations resulting from the operative acts [of the parties expressing their assent], consisting of a right or rights in personam and the corresponding duties, accompanied by certain powers, privileges and immunities." Add "and rights"-as that third parties shall nut induce breach; and disabilities under some phases of the pre-existing rule; and liabilities, as to taxation. I hasve elsewhere indicated my own view that from the counsellor's predictive puint of view the central contractual right is the contractual duty, simply seen from the other end. Both are statements of a single relation between $A$ and $B$, to wit, that if $A$ does or does not do described things under described conditions, $B$ can effectively sic the court on $A$. Brarsele Busr (1930) ch. V. But from the point of view of morals, cconomics, accounting, social relations, or normative law, the right is well said to correspond to the duty of equivalent predictive content. Part of the predictive description is of course the degree of certainty that the court will bite, and how hard.

28. Compare Cook's discussion, supra note 17; or the problem of deicetive shipment on order, infra, p. 812. 
error will become an error in or about the outcome of cases. For your good sense on how cases ought to come out will not always carry through. And if you still believe that you must find a second promise in order to establish a mutual contract-or to establish either half of a mutual obligation which is contemplated-then even when you have a very clear and satisfactory expression of agreement you are likely to not see it, or to disregard it, unless it can be wangled to look at least a little like it "promise". This will be bad for the accuracy of your doctrine, if courts are continuing to give effect to non-promissory expressions of agreement by offerees; and will be bad for the wisdom of your doctrine, because the courts will in so continuing be very sensible.

\section{A Principle for Applying Orthodox Principle}

What this matter of promise and agreement comes down to is this: that no one has yet isolated and formulated an adequate criterion for defining the field of law which we know as Contract. A definition is a phrasing which has two essential functions: it includes everything proper to include, and it excludes everything else. No definition of the contract field which I have seen includes everything proper to be included; but the same definitions rarely include anything which does not belong. Their trouble is in not including enough; hence taken as criteria for exclusion, they throw out good wheat with the chaff. Nor has any writer on Contract whom I have read ever stayed with the exclusions dictated by any definition he has cared to make. As illustration: I find Williston (who defines in terms of promise) treating release of a tort claim or accord-and-satisfaction thereof, under Contract; ${ }^{20}$ so does Corbin (who defines in terms of resulting legal right) $;^{30}$ and if a writer defines in terms of agreement, that will not keep him from treating of "promissory estoppel", or waiver, whether he approves of them or not. There is nothing peculiar about such being the situation in a field so heavily conditioned by history. But the fact contains a lesson:

Promise and Agreement, between them, do cover a very large portion of the historically given field. But they cover it as heavily overlapping circles cover an area on a plane: much of the area can be attributed indifferently to either, but not all of it; and to deal with the whole, there must be appeal not to either, but to each. And still to be done is $\mathrm{p}^{\circ}$ sustained thinking through, over the whole field of Contract, of the relation between the two-or of the relation of either to that whole. The more recent focussing of contract-thinking upon Promise has been fruitful for inclusion of needed material, and doubly fruitful for reorienta-

29. One cannot believe that this would today be regarded as a matter of unsealed "covenant" not to sue. But history makes it part of Contract.

30. E.g., Corbin, Cases on Contracts (2d ed. 1933) ch. II, § 3. 
tion. But it makes a bad premise for c.xclusion. For, I repeat, the courts have never departed from their sound feeling of a century ago, that Agreement had a major part (not a solo part) to play in the law of contracting. ${ }^{31}$

One can go further, and even risk the formulation of a Principle for the Application of Orthodox Principle:

"Any contractual obligation stated by classical orthodox principle, on the side of Offer and Acceptance, to have been incurred, has been incurred indeed; and this is true with almost equal flatness of the Restatement's rules. On the positive side, both are admirable.

But both older and modern orthodox rules and principles are utterly untrustworthy guides to when contractual obligation has not been incurred. On the negative side, both are not only false, but often vicious."

This is here stated too broadly. ${ }^{32}$ It will be reformulated more accurately at the close of this paper. It needs obvious qualification, for instance, in the manner of jug-handled printed forms made into "contract" when one party signs or takes a document whose content he cannot in fact he thought to have bargained or even known about. Nonetheless, it is worth overstating here in order to bring out the point that orthodox rules and principles have on the side of inclusion been doing work much like the work of good case-law judges : seeing things which need doing, and getting them done. Whereas on the side of crclusion, these "rules" and "principles" have been doing what common lawyers are less good at : reasoning in would-be systematic fashion from words very broad in scope, and reasoning without the cases and the case-situations and the people in the constant forefront of the mind.

The principle stated is intended as equally good for judge and counsellor. When orthodox rule and principle say that there is legal obligation in contract, they are, save for the small but important qualifications

31. Apart from accord, already mentioned, consider account stated which beeause it fixes the amount of a debt is quite as much a part of Contract as compromise; or attorneys' stipulations, which promise nothing, but are binding "promises"; or the effect of fraud on "executed" transactions; or release; or waiver "agreed to"-especially waiver which does not look to the future. Or consider implied warranties in present sales or other transfers, or the effective of misdescription and the like in an attempted mortgage, or representations as "express" warranties, or a bank's payment over a forged indorsement treated as a promise to pay the true owner, or even the problems centering on when a collecting-drawee bank becomes liable for the amount of the paper. "Promises" made up out of whole cloth are duties arising from agreement or relation, not from promising.

Compare the very interesting discussion of earlier views in Harding, Williston's Fundamental Conceptions (1938) 3 Mo. L. Rev. 219; also 1 PAcE, Conmucts (2d ed. 1919) ch. III.

32. For a preliminary sketch of the lines of proper limitation, see my review of Prausaitz, Standardized Contracts (1939) 52 Harv. L. Rev. 700. 
to be added, accurate for prediction, and also state good policy. When they say there is not legal obligation in contract, they are repentedly not to be trusted in regard to prediction, nor as stating good case-law atuthority for so holding, nor as indicating a wise holding.

\section{A Single Approach to Acceptance for All Business Deals?}

If we check back now, we would seem to have arrived at this: where the business bargain concerned envisages postponed future performance and mutual legal obligation, its formation is badly dealt with by the formula of offer "of a promise for a promise." This is, first, becatse there need be no promise given, in order to obligate the offeror. And it is, second, because much more than any promise (even if a promise is given) was called for, bargained for, envisaged, as the return for what was offered.

But it is third, and most importantly, because we are concerned in Offer and Acceptance not with an ultimate legal effect, but with an initial or, better, interstitial one. We are concerned with watching an offeror get to the point where his (or their, or its) own change of mind and motion will no longer be enough to remove court-threat for failure to go through with performance of the offering promise. When that milestone is passed, we say "There is a contract." What we should be saying is more nearly: "And so this transaction comes of age, and becomes a contract. It herewith passes beyond its offeror's sole control. But its early manhood, its maturity, its old age, all lie ahead; and it will change its very character as it gets on in life." That there "is a contractual obligation" does not mean that the obligee has or ever will have ground for a successful law-suit. In all but odd cases the obligor will be entitled to get or be offered all the actual juice of counter-performance which he bargained for, before he is himself called upon, in law, to perform. And if he does not perform, then in most cases the courts will exact from him not performance, but damages; and notification that he is not guing to perform will put it up to the obligee to take reasonable steps to cover, or else the court will refuse him any damages traceable to failure to take such steps. That we reach the stage of there "being contractual obligntion" means thus that the obligated outfit can no longer, by mere say-so, call off both deal and court. ${ }^{33}$ Whether reaching that stage means very much depends upon the deal, and to that we shall recur.

We need here to remember that to produce the stage of there being: such legal obligation on the offeror, in these cases envisaging mutul legal obligation for future performance, we seem definitely to observe:

33. I remind again that no implication is intended as to whether, e.g., a brolier who is called off before his sale is made, or ripe, may not be limited, if he sues, to his out-ofpocket; and also that it is the offeror's promise which is here under primary consideration. 
(1) that it is not necessary for the offeror to get more than a first down payment on what he wanted, and that a small one, to wit, the nere incurring of legal obligation by the offeree; and

(2) that it is not necessary for the offeror even to know that he is getting that much; and also

(3) that it is not necessary for the offerce to do anything beyond saying or writing words and sending a letter.

What seems to make the offer stick is a combination of something got by the offeror and something done by the offeree-neither amounting to the substance of what was bargained for. What the offeror is required to get is little; but perhaps we should add as one of its main elements: (4) "a high probability-in-fact that he will in due course be promised that the rest is coming through." What the offeree is required to $d o$, in the way of disturbing himself, is very little indeed. And the untutored layman might, if he were presented with such facts about law. well guess that if the offeree should really get to demonstrably building his action in terms of the offer, and so doing more, this might lead courts to making the offeror's promise stick with even less return to the offeror -and doubly so, if the lines of the offeree's action were such as to produce an increased probability in fact that the offeror would ultimately get the desired performance-an increased probability not from the offeree's words, but from the fact that the offeree was busy. The layman, in a word, might guess that in a soup so thin any observable chunk of meat would draw the attention and interest of the court whose threat might be concerned.

The legally tutored mind, on the other hand, will observe that the soup is thinner than has been indicated. If it had been the desire to reason from fascinating but ticklish and peculiar cases, it might have been argued that when the offeree is an infant or the offeror a non-complying corporation or guilty of fraudulent misrepresentation, the offer is made to stick: without the offeree ever losing the power to get out at will; ${ }^{3 /}$ or that if the "offer"-a "counter-offer" - is a slightly but unduly delayed attempt at acceptance, some courts find it unnecessary for the counter-offeree to do or say anything at all, in order to be obligated. ${ }^{35}$ But there is no desire to reason from the uncommon; lost letters and letters recalled from the mail are referred to in the above, for instance, only because they test

34. See especially Oliphant's notes in Selected Reanras (1931) 396-397.

35. Phillips v. Moor, 71 Mre. 78 (1880). The effort of Restatement, $\$ 72$, to minimize such cases, as also the pinning of ambiguous silence upon the unexpressed intent thereof to determine its effect (which in a systematics centering on overt manifestations is, one may suggest, almost lewd) turn on unwillingness to recognize the patent fact that sometimes courts hold one party to an envisaged mutual obligation when they will not hold the other. Not often; but when they feel an adequate reason. This is better dealt with by recognizing the fact, and trying to get the reasons stated. 
whether the courts really do mean what they say about the pervasive and ordinary cases. Do the courts really mean it when they "rile" that a letter of acceptance bars revocation when mailed, in all cases? Plainly, most do; for in the test, in the hard cases, they stand to that position. That gives a solid and a general measure of the thinness of this soup of what the offeror must get.

So that the question presents itself: If there is any other type of Contract to be considered, how little must the offeror get there, of zihat he wanted, in order to be barred from revocation; or, hove little must the offeree do, to bar revocation by the offeror? It is not a queer thing, it is a normal thing, for courts to be interested in business deals. It is not a queer thing, it is a normal thing, for them to become interested in such deals early in the deal's life. But courts require assurance that a deal is on, and meant, and worth their interest. How much, or better, how little, is needed to give them that assurance? It will be very queer indeed if that question does not prove to be pretty much a single question for all contracts, in life - at least for all "informal" contracts. It will be queer, too, if the answer to the question does not vary somewhat according to circumstance. But it will be even more queer if the circumstance which makes for the variation proves to be whether the offer was "for" a promise" or "for an act," unless that be a type of discrimination which parallels somewhat roughly the informal understanding of informal people closing informal business deals in a business-dominated civilization.

\section{When Should An Offer Stick?}

The American business man draws no sharp distinction in his deals between the promised and the accomplished. Our market does work in its legally more important parts on credit and future arrangement; but it works so strongly and so surely in those terms that future arrangement tends to merge into the present. My "net worth", which is a concept of the present, is, for substantial purposes, the difference between two future concepts : what is owed me less what I owe. My fixed assets (themselves valued in terms of expectation) are my troublesome assets; they are not liquid, and so merge less easily with the future. My income statement, not my "capital" statement, tells the story of whether I "am" good for a prospective loan: it is the past, read as a prophecy.

Agreeing for the future is so normal and so thoroughly relied on that as to individual deals it takes on to the layman in his ordinary thinking indifferently and without discrimination the guise of an accomplished something or the guise of a something merely initiated, or both together. It simply "is arranged". Beside such lay concepts about individual deals as loan, credit, dating, commitment, "future", booking an order, run stuch others as sales made, needs filled, notes closing an account, checks as pay- 
ment, and cash in the bank: when the loan is "on", the account is credited. Each of these last concepts is an instance of futurity observed and flatly felt as present; the future phrasing and the present phrasing about a deal are commonly synonymous. Either expresses both. Once the agreement is concluded, once the deal is closed, the outfit which will need supplies or service is "covered", it can put on a sales force to "sell" what has been "bought", cease "buying" itself along the line in question, go into the market for complementary inventory or materials for manufacture. If there develops a delay in delivery, the chances are even that information to that effect will run in about "your goods" rather than about "your order". And the outfit which is to furnish has "made a sale" and proceeds to arrange accordingly its ather "selling", its "purchase" of raws, its hiring, its production schedule, its financing.

Now if this be the way that deals are viewed in life, when nu clouding doubt about performance forces eye and tongue into meticulous discrimination, then it is not courts' business to be looking for acts in contrast to promises, or for promises in contrast to acts. It is their business to be looking for oz'ert expression of agre'ment - any overt expression of agreement. For with orert expression of agreement it is to be expected that the participants in the deal will rely soon, and will rely hard, and will rely in intangible ways absurdly difficult to prove, upon the deal so closed. That expectation may properly be standardized, for it is standard. It would be hardship in fact, it would be felt as injustice, to put any plaintiff to his detailed proof. "Should we not frankly" recognize," wrote Ballantine, "that promises [I should write: 'obligations'] may be bought on credit?" 36

The case is thus made, in ethics and in policy, for some type of legal remedy when agreement has been expressed. and each party knows of the other's expression, and a bit of time has elapsed. The case remains to be made, in ethics or in policy, for the snapping of the legal trap when the attempted retraction rolls in so quickly that any action talien in reliance becomes questionable, or when the quantity or degree of action taken is patently slight, or even when the retracting side can demonstrate the absence of any such action. Plainly, in such situations, policy hecomes more tenuous; and to my mind only resort to formalism can keep ethics from openly acknowledging "moral" obligation to be here often on slippery footing. Neither do I believe it possible to find a consistent ethical basis for all the rules evolved by our courts in the matter.

What I think I see here is this: First, and most, a contagion of attitude from deals where there has been no attempt at early retraction, and where it is plain that the deal has been, shall I say, lie'd into, and where men's minds and courts' minds then naturally (though quite without necessity)

36. Selected Readings (1931) 344. 
date the closing as of the easiest time to see and think about: to wit, the time when agreement was expressed. When minds have really and unmistakably not only met but joined up, neither a precise process nor a precise instant has importance. But we pick a mile-stone. This sets a picture of non-inquiry into any "how much" or "whether" of denonstrable overt reliance; an inquiry which is administratively baffling, anyhow, and to be avoided if may be. Upon this plays the fact that, in life, expressed agreement does operate as a commitment. It just does. It is true that not every commitment in business life is a commitment in law. It is hard to find words, for instance, which more definitively commit in business than: "This offer is firm till Tuesday noon;" words which seem not to bar revocation in law. ${ }^{37}$ But where agrecment is involved, Offer and Acceptance in regard to contractual obligation inherits not only a lay but a judicial ideology that goes back to and perpetuates itsclf in present dickers which are effective and complete with the final expression of agreement: "Take it for twenty, then!" "Done." This ideology, not of dicker about obligations, but simply of dicker, is what seems to me to make the legal view of how little is needed to commit the dickerer mould itself here so neatly upon the business view. Whereas the business view, which might otherwise shift (with the shift of the deal into future obligation) into a great measure of flexibility in freedom to call deals off, is stiffened in the older dicker pattern by two factors. The first is that of calculation and records. It is with the closing of a deal that the deal gets into planning, onto the books, onto production schedules, into the marketing layout, into the balancing of an inventory. To allow free retraction is uncomfortable and disturbing, both vaguely and demonstrably. It unsettles, and the whole measure of that unsettling is not easy to see in advance. But especially unsettling would free retraction be in regard to the second though less frequent factor: the closing of deals for the very purpose of shifting or hedging against the risks of market fluctuation. Deals in an unsettled market, or deals in a market which one party conceives as likely to shift, are deals whose essence is immediate shifting of price-risk quite as much as it is performance of the deal as made-and sometimes more so; deals therefore where certainty as of the moment of the closing goes to business essence, and proposed retraction becomes not a reasonable proposition for business rearrangement, but an attempted welshing - a very different thing from, say, a request two months later for some price readjustment to partly meet a general calamity in the trade. And it is these price-centered, jumpy market, deals which

37. On the bankers' credit situation compare (1938) 48 YALE L. J. 20, and note 41. We do not know for certain whether the credit sticks without overt reliance. I hope in a later article on Consideration to show an adequate technical device for maling not only bankers' credits, but firm offers, stick. 
play the lead, or at least one of the leading roles, in the great pageant of litigated cases on business Offer and Acceptance.

The net effect has been to make verbal commitment commit in law along wholly standardized lines, in which the ethical and even the policy considerations of any individual case are lost from notice. Commitment by action is not different, and calls for no other or different inquiry: So standardized, so routinized; so as of course is the ensuing of court-threat on overt expression of agreement that the court does not pause to consider whether the law of conditions may have failed to work out for this particular obligor that protection which is somewhat tacitly assumed to stand between any obligor and pressure to perform without assurance of return. Take an offer to deliver five hundred barrels of linseed oil to a dealer a month hence, and on sixty days' credit. The dealer's posting a letter which says "We accept" will spring the trap. Let the market price double before the letter is received; that will make no difference, irrespective of the dealer's non-change of position in reliance. Let believable word also run in that the dealer, though technically solvent still, is fast headed for the rocks; again no difference. Certain to lose an amount equal to the price, and almost certain to lose his oil for no return if he delivers, the offeror is held still to deliver or answer for the full value of his promised performance. As of course.

Now if courts are ready to move thus speedily, thus early, one can almost say thus ruthlessly into threat against an offeror when he has used mere words, surely it will be a queer thing if the offeree's demonstrable action and change of position in reliance on a promise does not move them. If they are thus willing, even to the point of outrage in such a case as that put, to disregard any need at all for performance of conditions by a promisee, before they hold revocation barred, and to discard eren any need that the offeror know that the deal is on before the trap snaps as the letter drops in the box, then surely it will be a queer thing if in another case they should require conditions to be performed to the uttermost inch, before they could be moved to bar revocation. In a word, the older orthodox conception of "the unilateral," when it sought to equate the minimum effective acceptance-in-law with full performance, was not only unjust and inequitable. It was worse: it was so improbable as to scandalize good sense.

Yet that older doctrine long held sway among intelligent scholars. Nonsense has not the habit of long holding sway. The reason why the doctrine managed as well as it did lies in the fact that in two classes of case to which it was applied it gave relatively little trouble, and gained from both some surface appearance of support. The one type of case can be called a pseudo-unilatcral, an agreement-based deal which happens to be performed substantially at one stroke, without prior promise: say, shipment of goods on order. It is not truly a classical unilateral, because the 
offer concerned can be accepted equally by a promise; but a court has no occasion to insist on this in any case in which all that is needed is to rule that acceptance has occurred; and the ruling can then seem to support "the" doctrine. ${ }^{38}$ The second type of case, of which a non-business type is the reward, and a business type is a promotion-brokerage deal, may be called the offer for a speculative prize. Not only is the offeror interested only in success, but no quantity of time, labor or money expended by the offeree can be regarded, until success, as moving with business certainty toward the performance-there is no effective assurance of performanct to be had from either verbal promise or from efforts made or from both. And, typically, the recompense promised is vastly greater than the worth of the offeree's time and skill measured on a pure per diem and out of pocket basis. In such cases it is often worth the offeree's while to gamble his time and energy and expenses, though he lose the stake; the reward and contest cases invite such gambles by many, with the prize to but one or a few, and they then flavor "the" doctrine, even in the business field, with some appearance of both justice and probability "for" tuillaterals", they seem to urge that interstitial reliance is just rislied, in "offers for a unilateral." 39 Moreover, whenever the more outrageous results are urged by defendants, when revocation is attempted after practical completion, the courts by talking "good faith" or by construing the conditions-in-law of the offer to be different from what the express clauses or words literally denote can bar revocation without revealing the pointblank challenge thereby raised to "unilateral" cloctrine in its strictest form.

When, however, the action of the offeree. is cumulative. and moves with some certainty toward the objective of the offer, the "principle" of unilaterals has met open challenge. If that challenge be yielded to at all -as the Restatement did yield, in Section 4.5-inquiry is invited into the unstable basis on which the "principle" rests which is found both unjust and contrary to case-law in the situations concerned in that section. Such inquiry will scoop out of the scope of "unilateral" doctrine the bulls of

38. We have been taught to think about the doctrine of unilaterals. That (1) requested performance will obligate an offeror, and that (2) only requested performance will obligate an offeror and that (3) only complete requested performance will obligate an offeror, have the garb of a single doctrine. They are not a single doctrine. They are three different, three wholly and utterly different doctrines. And cases holding the first point give by their holdings precisely no support for either the second point or the third. Their reasoning may give such support, either superficially or actually. Even that is infrequent. And I remind again that a court intent on holding the offeror because performance has occurred has no accasion to meditate at length on whether a promise, for instance, would not have done as well.

39. Even in these cases, however, there is a reason against allowing revocation: an offeree puts in his effort, expecting to have at least a fair gamble, not to be handed the loaded dice of revocation. But this goes only to time and money expenditure. In wholly non-business cases, like rewards for capture of criminals, this element does not secin to me to be present; there is a double chanciness fairly in the picture. 
what has been thought to fall within it, and especially the pseudo-unilaterals which are in fact agreement-based. As to the scant remainder the question then recurs: where active agreement is negated in advance as having any legal effect, then how much-or how little-is needed, to accept, as against the offeror?

\section{Agreentent-Based Deals v: the Odd-Lots}

The offeree's "expressing agreement," or more properly, "expressing active agreement," and "the deal being on" have thus far been used without taking distinction between the two phrases. If one examines them more closely, in their meaning-in-fact to people, one observes that a deal is on because agreement has been expressed. "To agree" may" indicate a state of mind, but to express active agreement indicates an action; the action occurs and ceases to be, leaving behind a result; the result is a relation which continues even though states of mind change: the deal is on. Its on-ness bears, in the field of fact, the same type of relation to the expression of active agreement which in the field of law the continuing power of acceptance bears to the occurrence we describe as an offer. And the problem now to be put, in the fact-realm, is much like the query: can a power of acceptance be created by any other means than by an offer? To which the answer. I take it, is: a power indistinguishable in effect is sometimes, though rarely, indeed created by other means. So here: that relation in fact between two people which we call a deal being on (and which claims to be a proper basis and ground for the relation in law we call contractual obligation) is indeed sometimes, though rarely, created by other means than expression of active agreement.

The situation is not too hard to see, despite some difficulty in describing it.

First, overt expression of active agreement is the normal and natural way of closing a business deal.

Second, any performance by either party which plays into the deal, and lies in the future, is with the completion of overt and active agreement normally and naturally interpreted as to be performed by such party; to be performed not as a mere contingency, but as a matter of business assurance and of business obligation. To negate this, circumstance or language will require power and precision.

Third, deals which do not involve an assurance of bargain-return to one side are initially suspect. One must doubt that they are business, or meant as business, at all. Unless their circumstances show persuasive business reason for their existence as deals, they are unwisely read as business deals which are "on", in fact. 10

40. An uncle's offer to guarantee purchase by his nephew of stock in trade; employment purely on commission; the "let-us-install-it" type of selling, are instanees where 
It is these facts which give power to the century old approach of courts to Contract as resting simply in overt agreement. It is these facts which bring courts to make an agreeing-by-language stick, even though the offer may read superficially as if it "called for a unilateral". It is facts like these which have led the Restatement to lay down in Section 31 that "In case of doubt it is presumed that an offer invites the formation of a bilateral contract by an acceptance amounting in effect to a promise by the offeree to perform what the offer requests"-language which, if it stopped there, and were given no negative implication, would be moderately apt. And Section 31, just quoted, shrewdly phrases the "acceptance" concerned as one "amounting in effect to a promise," thus avoiding any requirement of promissory language, and opening a welcoming door to what may be called loosely "promissory conduct", or called more accurately "action unambiguously referable to the offer, and unambiguously moving toward performance of it, which amounts therefore to an overt expression of active agreement, and normally imposes obligation on the offeree as well as on the offeror." Courts have in the past sought to express the juice and body of sense which urges recognition of this type of acceptance, by some such statement as that "by the offeree's entrance on performance, the contract, which was originally unilateral, takes on a bilateral character;" 41 and writers trained in the older orthodoxy lave been moved to criticise them. ${ }^{42}$ The modern orthodoxy of the Restatement goes far to disavow such criticism. For under Section 63 an offer for a bilateral can be turned into a unilateral by performing instead of promising, so that even what is conceived as transmutation is treated as no longer discreditable per sc. And under Section 29 an offer "may contain a choice of terms". Finally, under the language just quoted from Section 31, one can surely urge the offeree's interpretation itself as bearing on the presence of a "doubt". The suggestion or even implication of the Section, although not its expression, is that when a promise or other conduct-of-agreement occurs, a sufficient "case of doubt" may thereby be presented. For: "Doubtless wherever possible, as a matter of interpretation, a court would and should interpret an offer as contemplating a bilateral." 43

business reason appears. James Baird Co. v. Gimbel Bros., 64 F. (2d) 344 (C. C. A. 2d, 1933) presents an instance, on its facts.

41. Compare the much discussed Los Angeles Traction Co. v. Wilshire, 135 Cal. 654, 67 Pac. 1086 (1902).

42. As a good example, see Wormser, The True Conception of Unilateral Contracts Selected Readings (1931) 307, 311: "most curious," "astounding," "magical process," "needs only to be stated to refute itself." Ashley did not like such reasoning, either. [Sce Offers Calling for a Consideration Other Than a Cotmter Promise, Selected Rendrngs (1931) 293, 296]. But he liked the result.

43. Wilziston and Thompson (1937) $\$ 31 \mathrm{~A}$ or 60. 
But even in thus reforming case-law doctrine to more closely conform to case-law, the Restatement bogs partly still in the traditional dichotomy. The Restatement finds it not enough to recognize that the offer in case of doubt can be turned into a mutual obligation; such an offer must be further stated in Section 31 to invite this "rather than the formation of one or more unilateral contracts;" and the same "rather than" addition follows in the passage quoted from Williston and Thompson. It is an addition both arbitrary and wayward. As Whittier well points out, the true presumption is that either is called for, and called for indifferently. ${ }^{44}$ We meet in Section 31 the type of over-correction, or miscorrection, which is the common further fruit of an initial analysis which has set up the whole problem in a misleading way.

The same three facts mentioned above go far to explain how orthodox unilateral theory came to gain acceptance among teachers, despite its awkwardness in dealing with actual business bargaining. Since it is true that expression of agreement is the normal and natural way of closing a deal, the legal mind is tempted to conclude that it may be the only way of closing one. Hence, even as doctrinal emphasis shifted from agreement to promise as being the essential subject-matter of Contract, agreement was yet dragged along as a secondary essential attribute, and was called for in the requirement of "mutual assent." It will be noted that the change in term carries a change in flavor. "Agreement" connotes active obligation; and connotes commonly overt expression. "Assent" need not; its actual flavor is satisfied by mere acquiescence, in silence. This leaves the obligation aspect of the agreement-idea free to center on, and to become obscured by, the term "promise". In the wide range where - to recur to a figure used earlier-the circles of agreement and of promise overlap, we have seen that this persistence of the agreement-idea has great value. But where they do not overlap, and a single formula involving "assent" is applied to two quite diverse types of transaction which produce an obligation that runs one way only, there results confusion. The two types, as the Restatement has perceived, are the transactions which rest on active agreement-in-fact and those which do not; but the Restatement does not perceive the significant cleavage, and so,

44. The Restatement of Contracts and Mutual Assent (1929) 17 CALIF. L. Rew. 441, 453.

45. Whittier well indicates that Restatement $\$ 63$ (in an offer for a promise, full performance within the time set for promising will obligate the offeror; so will full tender) is made necessary chiefly by $\$ 31$ having first created "pure" bilaterals which then need to be got around. Whereas it is clear from Goble, Is Pcrformante Altusys As Desirable as a Promise to Perform? (1928) 22 ILL. I. REv. 789, that $\$ 63$, correcting the over-correction of 31 , is itself an over-re-correction; it should not cover all offers acceptable by promise: "The qualifications needed to make a supposedly simple basic structure give accurate results in practice reach the point where the simplicity is overwitelmed by its own qualifications." 
while making a glorious contribution to doctrine in the very conception of "Contracts Without Assent or Consideration", remains far from helpful as to case-law or theory of one-way obligations, whether they are not, or whether they are, agreement-based. ${ }^{\mathbf{4 6}}$

To these latter we turn first. And it is well to introduce them by rephrasing their description. The type of case in mind is the business deal which does rest on overt expression of active agreement, but whicrc only one party has anything left to perform.

When goods which conform to agreement have been delivered on credit, the resulting obligation is precisely the same obligation, whether or not there has ensued before the delivery a long period or a short period which can be termed a period of preexisting mutual obligation. Or, tusing more conventional phrasing, and using again Corbin's neat analysis by way of the successive steps in the life history of a contract, put it thus: a huge bulk of the unilateral contracts important in business life (wage claims and retail deliveries excepted) are "formed" by one contractor's completion of the conditions of a preceding bilateral. They are a residte from a mutual obligation.

Now this ancient truth is of great but neglected theoretical importance. It knocks, on the head any broad theory that no distinction is more fundamental than that between unilateral and bilateral, ${ }^{47}$ because a tmilateral is seen to occur as a natural process in the history of most bilaterals. What makes one occur appears to be the incidence of two things: first, an acceptance-in-law, and second, a completion of all duties assumed by the promisee. If the completion of these duties simultaneously accomplishe's all conditions to the now unilateral obligation, then, third, it also becomes an unconditional unilateral obligation. Frequently enough, the second and third matters, the accomplishment of duties and that of conditions, coincide; but we have learned the wisdom of keeping them conceptually distinct even when they do coincide in fact, or we should not have developed such an idea as "substantial performance", or "independent promises."

Does the same hold as to the first and second matters, (acceptance-inlaw and completion of offeree's duties), when they happen to coincide? It may be at once answered that they cannot coincide; that if a duty looks, by definition, to the future, it does not make sense to speal of it as assumed and performed simultaneously. No quarrel can be had with such an answer, for anyone who finds it useful. But I submit that for the present circumstance another line of analysis is much more useful,

46. See infra, p. 815 , on the difference between positive or active agreement and presumed assent.

47. "A vital distinction." Williston and ThOMpson (1937) §13. The discussion throughout the chapters on offer and acceptance makes clear that this is meant. I do not rediscover the passage stating that "no distinction is more fundamental." 
that line which keeps all three of the factors mentioned conceptually distinct. It is not in our law a novel or unfamiliar line of thinking, so far as regards assumption of a duty and its performance. We are familiar with covenants "broken when made", and the same type of covenant is much more likely to be performed when "made," and, therefore, never to have had existence as an obligation. Nor do I suppose that most of us have difficulty in seeing, in present sales of goods or negotiable instruments, implied warranties which we conceive as obligations but which are not broken, nor in conceiving an obligation-performed as the type from which the occasional broken warranty departs. Certainly the unbroken warranties are performed when made, in present transfers, so far as they relate to quality, genuineness and title. Analytically, therefore, they also never have existence as obligations. They have existence only conceptually, to help in dealing with cases in which they prove to have existence actually. ${ }^{48}$ So where all of the offeree's "duty" is telescoped into performance at the same single stroke in which by overt expression of active agreement the "duty" is "assumed", the question becomes one of whether there are related cases and problems which reward the intellectual effort required to see the case of telescoped duty and performance as being a telescoped case, in which two or even three conceptually distinct things happen to coincide, rather than as being a situation inherently different from the cases in which the elements are ubservably separate. There are at least three reasons why the more complex concept does reward such effort.

First, and as indicated, it lines up the formation of unilaterals out of bilaterals in the same conceptual scheme as those pseudo-unilaterals which, like immediate shipment of goods on order, have a surface appearance of having a significantly different line of origin. This helps. If, for instance, the shipment be seen as a permissible telescoping by the offeree, then it calls for neither worry nor explanation that on another offer of precisely similar character a promise to ship promptly should close the deal; and a tender by the offeree will carry an obligation to complete performance simply because tender is another obvious way of expressing active agreement, and no intellectual trouble is raised because it happens not to be a complete performance nor to involve an explicit promise. The analysis proposed thus makes for much smoother sailing in reaching results which modern orthodoxy creaks a bit to get, though modern orthodoxy has clearly recognized the need to get them. ${ }^{40}$ The slightly more

48. So Williston and Thompson, in \$1A, view "promises" as to present or past facts. And very rightly, in method. The question as to a concept is whether it serves its purpose of getting the results desired, of effectively manipulating the facts in the cuntext, and of not costing too much in the way of effort or confusion. The orthodox concepts cume at too high a price in both effort and confusion in the law's desired business of guiding decision cleanly and wisely on the raw facts as they emerge.

49. See supra, notes 44,45 . 
complex analysis of the case of shipment produces a vastly more simple net analysis of the whole body of cases on orders to ship.

Secondly, such analysis helps to see and deal with problems which orthodoxy even in its modern forms has much trouble in dealing with. I mention here only two, which are to be canvassed in detail on the cases in the next installment. Suppose the shipment we have been discussing is not in accordance with the order, though it has clear reference thereto. Orthodox analysis, lumping all aspects of the shipment into one, has been led or driven to treating it as a counter-offer. The approach here suggested can lead to treating it as an overt expression of active and effective agreement plus a defective attempted performance: an acceptance plus a breach. What the shipment says can be read: "We agree; and here is your performance;" and there is falsity and insufficiency only in the second half of this. That helps to hold those otherwise anomalous but very sane cases in which an offeror takes the defective delivery and then recovers for defects.

A further matter is that of action expressing overt active agreement, action which does not amount to full performance, and may incleed not amount to any performance at all. If acceptance-in-law is conceived, for all agreement-based contracts, as normally preceding full performance of "duties", then action by an offeree which is unambiguously referable to the offer will be easy to see for what it is, to wit, action expressing overt and active agreement, and so proper to effect acceptance-in-law; always with the accompanying condition ${ }^{50}$ of due diligence to notify the offeror that the deal is on. This appears only dimly, gropingly, partially, in the Restatement; but appears so often as to clearly evidence an effort to grasp and deal with the problem. ${ }^{51}$

In addition, with acceptance-in-law severed in thought from performance of conditions, the occasional non-agreement cases which involve lasting performance by an offeree fit comfortably into one's thinking; the question being that which has been pointed earlier: how much (or how little) must the offeree do to work an acceptance, a barring of revocation, as distinct from a right to the promised recompense? So that the third reason for using this telescoping analysis upon the pseudo-unilateral cases, those which are agreement-based, but in which expression of overt agree. ment, and assumption of "duty," and performance, happen to coincide in fact, is that this same line of analysis brings into sharp relief and

50. I leave for the next installment, with the cases in hand, the question of whether and when the offeree incurs a duty by expression of agreement short of letter-dispatch, and a duty to use due diligence to give notice.

51. To the matter discussed in notes 44 and 45 , add the effort in Resturtintent $\$ 45$ to give some protection in "unilaterals" whose performance lasts or where full tender is rejected; and Comment (b) to $\$ 52$, recognizing that "if a promise is requested" acts which indicate assent will do; finally $\$ 90$, protecting reliance on a promise in some circumstances. 
contrast those few cases in which the offer is clear to the effect that expression of agreement, no matter hori actiz'e and ozert, is to haz'e no effect at all on the offeror's obligation. To see that the coincidence in fact of acceptance with performance is peculiar is to see that more peculiar still is any offeror's anticipatory insistence that only by performance will he be obligated.

\section{-The Rarity of Non-Agreenext Deils}

Just how peculiar is such anticipatory insistence on performance alone, how abnormal is an offeror's unwillingness to take expression of overt and active agreement as acceptance-in-law, one sees by observing the illustrations put by orthodox writers to focus a given case as being in truth that classical unilateral to close which the offeree's words will be useless. When, in other situations, qualifications are heaped up to focus inescapably some particular point of law, the qualifications express the absence of disturbing factors which are unusual: they exclude fraud, infancy, supervening death, mangled code telegrams, the pointed pistol. Not so here. Here it is the every-day which is negated, it is the horse-sense ordinary line of interpretation and dealing which is expressly sought to be excluded:

" $A$ says to $B$, ' $I$ will not ask you to promise to install an intramural telephone system which will work perfectly in my building, but if you care to try to do it. I will pay you $\$ 1,000$ if you succeed. " $" s 2$

To bring home the rarity in living fact of a business deal in which words of active agreement by the offeree are nugatory, count the cases you have met, the decisions, in which such words have been held nugatory as acceptance of a definitive offer, because only performance could accept. The cases which come readily to mind are very different cases. They are cases in which there was action, and action was held sufficient to accept; their holdings do not show that they do not involve agreement-based pseudo-unilaterals.

To still further bring home that rarity, look over a few of the business transactions which overlightly candidate for inclusion under the classical unilateral concept. Do loans belong? I suppose friends are still "touched," who hand over a bill without a word. But most say "All right," first. And loans by banks, money-lenders, financing outfits-by lenders gener-

52. Illustration 1, from Restatearent $\$ 45$. It is characteristic of the degree to which modern orthodoxy has not thought its own renovations through that in the illustration "A rearokes his offer," whereas under the Section illustrated the offeror is already "bound by a contract;" and that $\$ 45$ is headed "Revocation of Offer for Unilateral Contract" although the text speaks only of becoming bound, and $\$ 41$ explains that revocation may be made if the communication is received by the offeree before he has excreised his power of "creating a contract by acceptance of the offer," and $\$ 52$ includes action under $\$ 45$ as being "acceptance." 
ally, other than pawn brokers-take the form of crediting an account (which is an incurring of obligation by the lender), or of handing over a check for the amount (which is again an incurring of obligation by the lender). And borrowers are rare who would repudiate a promise to make a loan as an unacceptable line of acceptance. Instrance has sometimes been thought a type of contract formed as a unilateral. Outside of twentyfive cent a week "industrial insurance," I do not find it so. Fire insurance "binders"; initial premiums "paid" by check, whether the check be given with the application or after approval; blanket coverage billed monthly according to user thereof-this is the picture as I get it, with most of it in terms of initiation by agreement and mutual obligation. That the period of obligation on the insured's side may be short is nothing to the purpose; nor that, should the check not be met, the company can cancel-for it can also sue and get judgment. Such is the situation in the modern world wherever the "act" is a payment, and the payment is made by check. But the evaporation of "unilaterals" in the open air of life goes further. Even the stock case of passing title to chattels as acceptance will-in addition to its "pseudo" aspects discussed above-be discovered on examination to fall, analytically, outside any "unilateral" pattern. ${ }^{53}$

53. After shipment in accordance with offer there is a remaining duty on the seller which does not rest on any other person, and whose breach involves a remedy not available to any other person, a remedy arising thus not out of property but out of the agreement. That duty is: not to stop the goods improperly in transit; and the peculiar remedy is to sue for non-delivery if he does, or, at will, to reject the delivery. Lynch Davidson \& Co. v. Denman Lumber Co., 270 S. W. 225 (Tex. Civ. App. 1925) (there was a prior contract for sale, but that makes no difference that I can see, under Unirowis SALES ACT, Part IV, and $\$ \$ 11$ and 67 and 69 ; the buyer rejected and had judgntent in a price action); and if arranging by C.O.D. marks to withhold inspection is a breach entitling to damages, Louisville Lithographic Co. v. Schedler, $23 \mathrm{Ky}$. L. Rep. 465 , $63 \mathrm{~S}$.W. 8 (1901) than $a$ fortiori is it a breach to withhold delivery by instructions to the railroad. These are not "property-right" consequences; they are consequences of breaking a contractual duty. The point is worth mention because it shows the supposed "pure unilateral" here not to be "pure," even when no questions of unbrolien warranty are involved. But it is even more worth mention for its bearing on general theory. It shows that after completion of what is conceded to be acceptance in a case currently considered to be one of a unilateral there may be conditions and even duties still resting on the offeree. The Restatement, in $\S 56$, lays down such a rule about due diligence in some cases to notify the offeror that acceptance has accurred. The duty not to stop improperly in transit not only serves to lend color to the Restatement's position in recognizing a possible succession of things to be done by the offeree, even after revocation is barred, but serves also to invite attention to the probability that the rule of $\$ 56$ may not be exceptional, but may be only one instance of many in which performance must be viewed not as a lump, but as a sequence.

$A$ fortiori is there a remaining duty on the seller when he happens to be the offerce in a face to face sale. His duty to deliver under UNIFoRMr SALES ACr $\$ 42$, or to proture attornment under $\S 43(3)$, survive the transfer of title and under $\$ \S 11$ and 69 entitle the buyer to rescind on breach or to accept and have damages. 


\section{"Assent" Where Agreesrent is Nugatory}

Though cases in which the terms and circumstances of the offer make plain that overt expression of active agreement is to be without legal effect are thus rare, they do exist. One recalls the case of the promotionbrokerage, put earlier; and a real estate brokerage case may occur in similar form, the offeror expressly denying his willingness to talie the broker's promise to list or advertise or hunt customers as having any interest to him at all. Similar cases can occur at the end of a protracted negotiation: "Promises? I am sick of promises. The only thing that interests me is cash. Fifty-six hundred on the line by Tuesday noon, or it's off. Put up or shut up." Or cases may arise in which an offeror is conferring a business opportunity, perhaps in a market the offeror largely controls; so perhaps an offer by a big local dealer to the petty lumbering outfits of a neighborhood: "We will take at so much all oak ties delivered at our boom by April next"-and one can readily conceive the circumstance to be such that no particular petty lumbering outfit's engagement to sperid the winter getting out ties would be of any interest.

If in some similar case it be decided or provided that overt expression of active agreement is not to work acceptance-in-law or to impose obligation on the offeree, that still does not mean the assent of the offeree is also nugatory in law. What it does mean is that the kind of assent in question is a pallid thing. It is for purposes of the offeree's proof in court wholly dispensable. Show, in a business case, the offer communicated to the offeree, and performance of the conditions by the offeree, and any assent which may be required in law is taken for granted. What matters is reliance, or performance of the conditions in their succession. Assent demonstrably enters the picture only in its active negation; somewhat as with the assumption of duty in a pseudo-unilateral, its presence in the ordinary case is perceived or conceived or assumed chiefly because of other cases: it is assumed here because there are some utterly freale cases in which the offeree, as he performs the conditions, explains that he is not acting with reference to the offer. ${ }^{\text {st }}$ One can express this by stating that, in these non-agreement cases, whatever assent by the offeree may be necessary is so strongly presumed that only his explicit and timely dissent will be operative to prevent his actions serving as acceptance-inlaw, and serving, subject to matters involving mitigation of damage, as in due course maturing the offeror's immediate obligation by full performance of conditions. Action or inaction, not assent, is under the judicial microscope. And if this be sound, one begins to wonder whether certain cases listed by the Restatement as being "without assent" do not involve a very similar type of tacit and passive "assent"-presumed-as a gift is said to, or a beneficial legacy. The matter is not of great moment,

54. For cases see WiluIstox Axd Thoxrpsox (1937) $\$ 67$. 
except for clearer thinking, any more than is the question whether parties must intend to enter a legal obligation in order to get one. The answer in both cases is : conceptually, Yes; actually, No. The courts care so little in practice whether the offeree's assent to a true unilateral is present, or whether any party intends a legal obligation, that they go ahead cherrfully without inquiry on the point; but they will not force on him a new contractual right over his protest at the time that nothing he is doing is to give him one. ${ }^{55}$

The line of thought does, however, sharpen the distinction between the vast body of contracts, those based in agreement, and the odd-lots. In the former the offeree's overt expression must, to be effective as an expression of active agreement, stand to proof as such, and bear weight. It is an operative fact crucial to the plaintiff's case for protection against attempted retraction.

\section{ExIt "The ACT"}

To get clear, however, that active agreement without performance will not work acceptance-in-law where the offer is unmistakably not for an agreement-based contract, is not to get clear what will work an acceptance. The problem is not easy. Its difficulty lies in there being no sharp and definite point, such as that given by an overt expression of agreement, on which to make acceptance-in-law turn. The older orthodoxy sought to solve this difficulty by ignoring it. Any degree of reliance demonstrated by the offeree, any number and importance of conditions which the offeree might have performed, were regarded as immaterial to acceptance-in-law because the full bargain-equivalent had to be given, to satisfy the requirement of consideration. Langdell's thinking had a gratifying quality of consistency in this field. If acceptance was to be by promise, then it was to be by an honest promise, and of course it had to be heard or received before it could be a promise. If acceptance was to coincide in the non-promise case with the giving of the full bargained-for detriment to the promisee, then that was exactly what was required. It helps to get perspective on the solidity of these premises when one remembers what courts have done to the "requirement" that a letter of acceptance be received before operation, and when one remembers that this identical universal detriment theory of consideration denies rights to beneficiaries, rejects any suit based on other-than-bargained for reliance, and seems universally conceded to have no application to the most important class of contracts we know, those of mutual obligation.

The difficulty with both premise and conclusion is hidden, however, in the class-room formulation "promise for An Act." The factual picture on which the phrase is modelled is either the pseudo-tunilateral in which the offeree's part is substantially accomplished at a single stroke-as in

55. Not so, as to contractual duties, of course. 
the transfer of property in a chattel-or the speculative prize case, in which only the end-result has juice. In such cases "Promise for an Act" has at least color of adequacy. The effect of the phrase, however, is vicious. For "An Act" does not seem susceptible of division. It is a unit. Any offeree's conduct conceived as involving "An Act" promptly becomes a lump, and slides away from analysis into its constituent parts. Anything short of "The Act" (itself pictured in terms of shipment, or payment, or winning the prize) becomes then almost by psychological necessity "merely preliminary"-which means, in law, nugatory.

The degree to which the word "Act" obscures perception is almost terrifying in its revelation of the power of a phrase learned early. That hypothetical trip to York in its own hypothetical time dragged out for days over roads that left horses mired to the withers. Building a carriage was no matter of a moment; and it was early in the books. Yet these facts hid themselves from appreciation beneath this one sharp word Act. What then of continuing in the promisor's service, procuring a franchise and laying ten miles of track, accumulating a cargo of staves on a landing, cutting and getting out a winter's cut of timber? Are such things conceived as being each An Act? They have been. Even more, observe the flavor of the word as it carries over to its sidekick "a forbearance." VYith the best will in the world, forbearance must still be viewed, if it be giried, as a continuing something. "A forbearance" as such is about as near to vacuum of content as a concept can be. Paired with "An Act," its vacuum escapes examination. Only unconscious resistance against letting the emptiness of meaning appear can explain our common practice of not substituting a word which forces thought-say refraining. That would make any student query in each case : Refraining from what? Refraining how? Refraining for how long? If the offeree begins to refrain from the particular action which he is requested to refrain from, is not that significant? If he takes important steps, such as "discontinuing" a product, a line, competing with the offeror's, is that not very significant -though non-reorder be but a "forbearance" over less than "para'um tempus?"

Hence to see these cases we must not only use words which do not hide lasting or complex performances under words connoting single-stroke action; we must also apply to the single-stroke instances themselves the same procedure which we have applied to expression of agreement. There we found lumped in a single face to face expression three important elements which in other cases need discrimination: overt expression of agreement, due diligence to give notification of agreement, actual bringing home of knowledge to the offeree. It paid to keep the elements conceptually distinct even when a single action was accomplishing the work of each. Again, in the pseudo-unilateral, we found it well to keep conceptually distinct the elements of expression of agreement and assumption 
of duty, fulfillment of duty, and fulfillment of condition. So, here, the basic picture consists of action in reliance; action in preparation which leads definitely toward the end result (such as hiring a crew and buying: supplies for a winter's logging); actual performance of a first condition (such as beginning to refrain) and a second and a third; and utter completion. If our preceding inquiry has made sense, it will be strange if somewhere along the line acceptance-in-law does not occur, and it will be queer also if it is not colored by consideration-thinking of the judicial. type: When has there been enough reasonable action in reasonable reliance on a promise to make that promise call for enforcement? The precise point is for the cases, and the answer may sometimes turn on the degree or kind of remedy sought. ${ }^{56}$ It will - there being no sharp turning-point to choose-be decided none too consistently. But this we may expect : only an occasional court, misled by theory which never should have been, will sufficiently forget the drive of fact, of justice, and of judicial analogy to make acceptance-in-law wait upon utter performance of conditions, unless the particular facts given excellent and particular reason to-unless the case be a freak even among the odd-lots. The question is that posed before:

How little, or how much, of action by the promisee is required to substitute for that overt expression of agreement which will not suffice, in these odd lot cases, to work acceptance-in-law?

What is in question is not "an act," much less "the act"; it is action or suffering in reliance, and a performance presumably complex and continuing in character; and the promisee's condltct will gain especial importance on the barring of revocation as it comes to give factual assurance that the desired performance will be completed.

$$
* * ;
$$

It is submitted that the suggested modifications in concept, doctrine and approach make the problems of initiation of business contract easier to see, and easier to handle, and that the proposed doctrinal structure offers for this branch of business contract law a more unified and simpler conceptual scheme than we have been accustomed to use. On the other hand, the proposals are submitted to be grounded in our tradition. They are easy to relate to the accepted doctrine, and they rest throughout upon familiar judicial concepts. The next installment will attempt to demonstrate not so much that the proposed modifications make for sense and simplicity (which has been the task of this installment) as to demonstrate that they hold the case-law and guide decision and prediction under it more serviceably than has our current class-room doctrine.

56. The possibility canvassed by Fuller and Perdue, that when only a "reliance" measure of damages is sought, it may call for less reliance to bar revocation, needs to be remembered; especially in regard to personally addressed single offerees, as distinct from competition and reward "groups." 